Lysicarpus ternifolius, F. v. Muell. This is what generally goes by the name of "Stringy Bark" in this part of the continent and as far as the bark is concerned it is very like the tree of that name elsewhere or Eucalyptus obliqua. But the leaves are very different and so I need hardly say, are the flowers. It is only quoted from one or two places in the "Flora," but I have found it forming the principal ingredient of some of the scrubs between the Comet, Nogoa, and Belyando Rivers. The fibre is of such a superior quality that it has been sought for by rope and paper makers, but hitherto the price offered has not been sufficient inducement for its collection.

Metrosideros chrysanthus, F. v. Mueller, which Bentham regarded as a distinct genus (Xanthostemon) was seen by me in many forests around Trinity Bay, on the Barron and Mulgrave Rivers.

Myrtus gonoclada, F. v. Muell. This tree is found in the subtropical forests as far at least as the Burnett River. The wood is called ironwood by the settlers, and is of extraordinary hardness. It would be superior to box for wood engraving. It is seldom above 25 feet in height and the stem is consequently small. Cedar-getters do not like to use their axes upon it. It is very common in shady places.

\title{
On a Coal Plant from Queensland.
}

By the Rev. J. E. Tenison-Woods, F.G.S., F.L.S., \&c.

The plant impressions which I exhibit this evening were taken from the Tivoli Mine near Ipswich, Queensland. It will be observed that amongst the fragmentary mass of leaf impressions in the clay, there are certain disk-like forms of rather an ornamental character. They are shaped like toothed wheels with a small central perforation and a radiate ring of pear shaped perforations near the edge. These disks are very abundant in 
some places and suggest the idea of fruits, but there are no known fruits of this character, either living or fossil. A little attention to the plant impressions by which they are always accompanied will explain their origin. These might easily be mistaken for Phyllotheca a closely allied plant, but they are not of that genus. The whorls of leaves at the free ends of the sheaths are never present. Instead of them we have the toothed closely adpressed sheath of Equisetum, which shows us that this is the genus with which we have to deal. Now Equisetum is a plant in which the stem is fistular and with one or two rings of longitudinal cavities in its circumference. At intervals the stem is divided by transverse disks, which have this single or double ring of cavities. The outside ring is seldom seen as this is the portion where the disks break away. As they contain a good deal of silica they are easily preserved, they are always found abundantly in the soft marshy ground on which Equisetum grows. We have no such plants existing in Australia, but they occur in all other portions of the globe except New Zealand. Formerly they played a most important part in the world's vegetation, and many believe that Calamites, Sphenophyllum, and Annularia belonged to the same family of Equisetacea.

Disks somewhat resembling the present have been found in the Oolitic Coal of England, and in the Upper Trias of France and Germany. At one time they excited some little controversy as to their nature, but there seems now to be no doubt of their cryptogamic character.

Equisetum is not previously recorded from our Australian plant formations. One species is described from the Gondwana beds in India, by Oldham and Feistmantel-E. rajmahalensis. This plant somewhat resembles our species, but the differences in the diaphragmata are great.

In a paper I am preparing on the whole of our coal flora in Australia, I shall deal with this species. In the meantime in the 
absence of any evidence that it is specifically identical with any described Equisetum, I distinguish it as E. rotiferum.

Nothing approaching the spore-bearing spikes was seen by me, so that the fructification must remain unknown for the present.

True Phyllotheca have not been met with by me in these beds.

\section{Observations on an Insect injurious to the Vine.}

By William Macleat, F.L.S., \&c.

At the last monthly meeting of this Society I exhibited some Coleopterous larvæ which had been found by Mr. Holroyd to have committed very serious havoc among his grape-vines. I also exhibited cuttings of the injured plants, showing the pith or centre of the branch completely eaten away along the entire length of the season's wood, with, in some cases, the devastation extending into the old wood and the roots. I said at the time that the grub was the larva of a Curculionidous beetle, but that until I had seen the perfect insect, I could not possibly tell the species or even genus, so much alike were all the larvæ of that group. I am now, however, able to speak positively on the subject.

A few days ago Mr. Holroyd brought me several specimens of both sexes, some-in coitu, of a beetle taken by his gardener out of the injured plants, and which are most undoubtedly the outcome of the grubs which had caused all the injury. I find them to be specimens of Orthorhinus Klugii, of Schönherr.

The genus Orthorhinus numbers about 20 species, and is found only in Australia and a few of the Polynesian Islands. The description of it, translated from Lacordaire's "Genera des Coleopteres, vol. 6, p. 462," is as follows: "Head subglobulose; rostrum much narrower than the head, rather robust, straight, cylndrical, longer than the head. Antennæ of moderate length, 


\section{$2 \mathrm{BHL}$ Biodiversity Heritage Library}

Woods, Julian Tenison. 1882. "On a coal plant from Queensland." Proceedings of the Linnean Society of New South Wales 7, 342-344. https://doi.org/10.5962/bhl.part.22756.

View This Item Online: https://www.biodiversitylibrary.org/item/30242

DOI: https://doi.org/10.5962/bhl.part.22756

Permalink: https://www.biodiversitylibrary.org/partpdf/22756

\section{Holding Institution}

MBLWHOI Library

\section{Sponsored by}

MBLWHOI Library

\section{Copyright \& Reuse}

Copyright Status: NOT_IN_COPYRIGHT

This document was created from content at the Biodiversity Heritage Library, the world's largest open access digital library for biodiversity literature and archives. Visit BHL at https://www.biodiversitylibrary.org. 